\title{
Peran Sekolah Kreatif dalam Mengembangkan Psikomotorik Anak di Rumah Belajar Tanah Merah Bangkalan
}

\author{
Abdullah \\ STIT Al-Ibrohimy Bangkalan \\ abdie649@gmail.com
}

\section{Article History:}

Received : 14-08-2020

Revised : 21-08-2020

Accepted : 23-09-2020

\begin{abstract}
This reseach describes creative schools in developing the psychomotor of students in the Rumah BelajarTanah Merah Bangkalan . this research qualitative research and a case study approach. The results of this research, The creative school designed by Rumah Belajar the Tanah Merah Bangkalan Learning House has the potential to increase the psychomotor domain of children, because edutainment methods, facilities. The facilities a re in accordance with the conditions of children and various outdoor and indoor programs, giving children the freedom to freely create and innovate without having to be too strict by school rules. In essence, they can learn while playing, in creative schools new innovations are needed, especially in teaching methods and classroom design in order to be able to present the fruits of their work from the age of 3 years to the age of 9 years. Besides that, there is a practical learning pattern. The children are directly invited to understand the lesson by practicing the contents of existing lessons. Like understanding the body structure of fish, they are invited to see the fish being dissected in front of the class.
\end{abstract}

Keyword: School of Creative, Childhood, Psychomotor Development

\section{Pendahuluan}

Pendidikan memiliki peran penting dalam memajukan sebuah bangsa. Pendidikan merupakan sarana dalam meningkatkan kualitas sumber daya manusia, dalam rangka mewujudkan kualitas sumber daya manusia diperlukan kerjasama dari masyarakat dan pemerintah. Perkembangan pendidikan di Indonesia masih menghadapi beberapa persoalan yang serius, terutama berkaitan dengan kualitas, relevansi, dan efisiensi pendidikan. Kementerian Pendidikan Nasional sebagai lembaga yang bertanggung jawab dalam menyelenggarakan pendidikan dan telah memperbarui sistem pendidikan. Upaya ini merupakan langkah untuk meningkatkan kurikulum, meningkatkan fasilitas dan infrastruktur, dan meningkatkan kualitas guru. ${ }^{1}$

\footnotetext{
${ }^{1}$ Ari Wijayanti. Pengajaran Bahasa yang Kreatif. http:// blogroll. Maret 3, 2020.
} 
Penciptaan manusia yang kualitas dan masyarakat yang maju dan mandiri hanya bisa diwujudkan dengan pendidikan yang berkualitas. Pendidikan merupakan sarana yang paling efektif dalam memajukan negara. Selain itu, perekembangan ilmu pengetahuan dan teknologi yang begitu pesat, membuat seseorang sadar untuk terus belajar supaya tidak ketinggalan dengan perkembangan yang semakin cepat. Terutama peran guru yang memiliki tugas mengajar dan mendidik. Jika seorang guru lalai dalam belajar, tentu saja ia akan tertinggal dalam perkembangan dan memiliki dampak yang nigatif pada kualitas pendidikan dan pembelajaran yang membosankan.

Guru profesional harus mampu menghasilkan citra diri pada siswanya, begitu pula tugas utama guru bukan hanya mentransfer ilmu, apalagi sampai menuangkan materi pembelajaran seakan menuangkan air ke dalam botol. Guru memiliki tugas menciptakan suasana pembelajaran yang nyaman sehingga anak-anak dapat belajar dengan serius (learning how to learn). Tugas-tugas itu bukan perilaku tunggal, tetapi harus difasilitasi oleh manajemen sekolah yang cerdas. Pemikiran ini membawa kita ke wacana lebih lanjut, bahwa kepala sekolah dan guru melakukan pekerjaan yang sangat berat, meskipun itu tidak selalu berarti hebat. Guru dituntut untuk mendidik anak dengan standar perolehan dan proses pendidikan yang baik. ${ }^{2}$ Meskipun pembelajaran terlihat berjalan secara sederhana dengan menjelaskan dari tidak tahu menjadi tahu, akan tetapi pemahaman dan penilaian jauh lebih dalam dan kompleks karena dalam proses pembelajaran guru tidak hanya melihat hasil belajar secara kognitif saja, akan tetapi guru melihat kemampuan anak dari beberapa aspek dalam proses belajar sebagai pembentukan makna atau dalam pembelajaran praktis adalah terjadinya pemikiran yang dilakukan anak ketika mereka mendapatkan konsep, sehingga apa yang mereka dengar, lihat, dan dilakukan di sekolah bermakna bagi kehidupan anak, setidaknya anak mengambil bagian dalam berpikir dengan tulus tentang topik pembelajaran. Dengan demikian, hasil ulangan hanya mewakili sebagian kecil kemampuan anak, karena bukan hanya hasil percakapan atau logika yang dapat dikatakan, tetapi kemampuan lain yang mencerminkan kehidupan. ${ }^{3}$

Dalam obyek penelitian di Rumah Belajar Tanah Merah Bangkalan yang menerapkan model pembelajaran baru. Ada beberapa capaian perkembangan yang sangat membanggakan, walaupun semakin berat tantangan dan hambatan yang harus dihadapi. Namun direktur rumah belajar terus melakukan gerakan dengan semangat pembaruan sesuai dengan semangat gerakan reformis. Salah satu perkembangan yang menggembirakan ini dapat dilihat dari respon positif masyarakat terhadap keberadaan sekolah kreatif ini. Meningkatnya jumlah siswa baru dari tahun ke tahun merupakan indikasi nyata bahwa model pembelajaran disekolah kreatif secara bertahap dapat diterima dan dirasakan manfaatnya.

\footnotetext{
${ }^{2}$ Sudarwan Denim, Visi Baru Manajemen Sekolah (Jakarta: Bumi Aksara, 2006), 13

${ }^{3}$ Aan Komariah, dan Cepi Triatna, Visionary Leadership "Menuju Sekolah Efektif” (Jakarta: Bumi Aksara, 2006), 33
} 
Salah satu perbedaan rumah belajar Tanah Merah Bangkalan dibandingkan dengan sekolah pada umumnya terletak pada model dan proses pembelajaran. Rumah belajar ini model pembelajarannya menggunakan pendekatan tematik. Ini berarti bahwa pembelajaran menempatkan siswa sebagai pusat kegiatan (student oriented). Oleh karena dalam proses belajar berusaha mengakomodasi perbedaan kampuan siswa (kecepatan dan minat belajar yang berbeda). Ini termasuk memberikan proses belajar yang bervariatif dan mengoptimalkan indera pendengaran, penglihatan dan fisik anak (visual, audio atau kinestetik). Di rumah belajar materi pelajaran tidak langsung diberi pada anak, tetapi diberikan materi secara terintegrasi. Berbagai mata pelajaran disajikan secara terpadu terkait dengan tema tertentu. Tema pembelajaran diambil dari hal-hal konkret yang ada di sekitar kehidupan anak seperti keluarga, hobi, binatang, tumbuhan dan lain-lain. Dari tema ini guru kemudian menghubungkan dengan materi pelajaran yang sesuai untuk mencapai kompetensi yang ditargetkan. Penerapan pendekatan ini bertujuan supaya anak dengan mudah menyerap materi yang dipelajari, mengingat pemikiran anak-anak pada usia 3 tahun 9 tahun masih dalam level operasional konkret. Ini berarti bahwa anak-anak yang memasuki sekolah antara usia 3 dan 9 memiliki citra diri positif dari kemampuan belajar mereka sendiri. ${ }^{4}$

\section{Konsep Pengembangan Sekolah Kreatif}

Sekolah kreatif adalah sebuah pengembangan ideal adanya institusi pendidikan. Dalam kamus besar dijelaskan bahwa sekolah adalah bangunan atau lembaga untuk belajar dan mengajar serta tempat menerima dan memberi pelajaran, waktu atau pertemuan ketika murid diberi pelajaran, usaha menuntut kepandaian. ${ }^{5}$ Sedangkan Kata "kreatif" berasal dari bahasa latin "crate" yang berarti menyebabkan tumbuh: menghasilkan, membuat dan mengeluarkan. Adapun Kamus Ilmiah Besar definisi kreatif adalah memiliki kemampuan untuk menciptakan sesuatu yang belum ada, menjadi kreatif. $^{6}$

Sekolah Kreatif Rumah Belajar Tanah Merah Bangkalan adalah lembaga pendidikan non formal yang merupakan wadah belajar secara gratis. Kegiatan di Rumah Belajar hanya pada hari jumat dan minggu. Rumah Belajar yang menyediakan forum sendiri untuk siswa dengan memahami karakteristik pola perkembangan anak. Sesuai dengan konsep sekolah kreatif bahwa anak-anak harus dididik sejak 3 bulan di dalam rahim ibu. Cara seorang ibu harus bisa mengendalikan emosinya. Karena secara psikologis, energi negatif dari emosi akan memengaruhi embrio janin. Hal ini didukung oleh teori yang menyatakan bahwa stres emosional yang berkepanjangan selama awal kehamilan dapat menyebabkan hiperaktif kelenjar kelenjar andrenalin ibu, dengan melepaskan lebih banyak hormon hidrokortison. Jika ini terjadi selama awal kehamilan, itu dapat menyebabkan penyimpangan fisik dan keterbelakangan mental.

\footnotetext{
${ }^{4}$ Sudarwan Denim, Visi Baru Manajemen Sekolah, 12

${ }^{5}$ Pusat Bahasa Departemen Pendidikan Nasional. Kamus Besar Bahasa Indonesia Edisi Kedua. (Jakarta: Balai Pustaka, 2002). 1014

${ }^{6}$ M. Dahlan Y. Al-Barry. Kamus Induk Ilmiah Seri Intelektual, (Surabaya: Target Press 2003). 427
} 
Sebaliknya, jika terjadi pada akhir kehamilan, yaitu selama periode janin, itu tidak hanya menghasilkan hambatan mental, karena otak terus berkembang pesat saat ini, tetapi juga mengakibatkan kelahiran prematur, kesulitan kelahiran dan kematian saat lahir. ${ }^{7}$ Emosi seorang ibu selama kehamilan harus sepenuhnya dikontrol, karena secara tidak langsung akan mempengaruhi kondisi janin dan kelainan fisik pada bayi yang menyebabkan gangguan mental saat lahir. Tidak hanya itu, bahwa sikap orang tua yang bermakna bagi anak seperti kesehatan ibu, nutrisi juga berpengaruh besar yang menentukan bagaimana perkembangan sel telur yang dibuahi.

Selama ini di kota apalagi di desa-desa banyak orang tua yang tidak mengerti kecenderungan bakat anak. Orang tua begitu mudah mengarahkan anak sesuai keinginannya. ${ }^{8}$ Pemaksaan keinginan orang tua untuk anak akan mempengaruhi karakter anak dan selanjutnya menjadi tembok pembatas untuk perkembangan anak. Padahal tidak semua yang orang tua inginkan adalah pilihan anak. Bahkan tidak sedikit anak-anak terpaksa menuruti keinginan orang tua mereka ketika memilih tingkat pendidikan. Ini adalah kesalahan yang berkepanjangan dan fatal. Untuk mengembangkan sekolah sehingga mereka dapat beradaptasi dan mengembangkan pola belajar mereka, sekolah kreatif menjadi konsep yang layak dipelajari. Kita tahu bahwa sekolah adalah bentuk organisasi yang sederhana. ${ }^{9}$ Sabab dalam mengimplementasikan pembelajaran sekolah kreatif Rumah Belajar Tanah Merah Bangkalan menggunakan pola pembelajaran kreatif yang berbeda dari sekolah formal. Mengenai metode pembelajaran yang diterapkan di rumah belajar ini adalah metode pembelajaran edutainment yang merupakan proses pembelajaran yang telah dirancang sehingga pendidikan dan permainan dapat terintegrasi secara harmonis.

Jadi belajar lebih menyenangkan. Belajar yang menyenangkan biasanya dilakukan dengan humor, game, permainan peran (role-play) dan demonstrasi yang membuat belajar menjadi menyenangkan. ${ }^{10}$ Pembelajaran yang menyenangkan bukan hanya sekedar pembelajaran yang mengharuskan anak-anak bercanda dan tertawa terbahakbahak, tetapi pembelajaran di mana ada kohesi yang kuat antara guru dan siswa dan siswa tidak merasakan tekanan. Yang ada adalah jalinan komunikasi yang saling mendukung. Pembelajaran yang membebaskan, sesuai dengan konsep Paulo Fraire, adalah pembelajaran di mana tidak ada lagi tekanan, baik tekanan fisik maupun psikologis. Karena, apa pun tekanan yang disebut hanya akan mengerdilkan pikiran anak, sementara kebebasan dalam bentuknya akan dapat mendorong terciptanya iklim belajar yang kondusif.

Sekolah kreatif memiliki setidaknya dua pendekatan untuk mengasah mental, pola pikir, dan keterampilan siswa. Keduanya adalah pendekatan untuk perilaku anak dan

\footnotetext{
${ }^{7}$ Elizbeth B. Hurlock. Perkembangan Anak Jilid 1. (Jakarta: Erlangga, 1997), 72

${ }^{8}$ Laila Munawarah, Wakil Direktur Rumah Belajar, 8 Maret 2020.

${ }^{9}$ Mudjijana, R. Hubungan Antara Iklim Sekolah dan Kecerdasan EmosionalSiswa dengan PrestasiBelajar Siswa. Jurnal Pendidikan Penabur- No.02/Th.III/ Maret 2004.

10 Sutrisno, Revolusi Pendidikan di Indonesia: Membedah Metode dan Teknik Pendidikan Berbasis Kompetensi, (Yogyakarta: Ar-Ruzz, 2005), 31.
} 
pendekatan untuk perkembangan anak. Kemudian dia menggunakan metode yang sangat berbeda dari kebanyakan sekolah di Indonesia. Guru di sekolah kreatif tidak boleh marah sama sekali. Bahkan jika memungkinkan, guru harus menjadi teman bermain anak. Menurut Rachmy Diana, kreativitas anak-anak ditekan sejak bersekolah, artinya mereka dibunuh terlebih dahulu karakter mereka. Sehingga secara alami, kualitas generasi Indonesia kurang berkualitas. ${ }^{11}$

Di sekolah kreatif, ruang kelas di atur sedemikian rupa agar anak-anak tidak bosan. Selain pola penyampaian materi, menggunakan metode mendongeng. Karena dengan dongeng, anak-anak lebih tertarik dan lebih mudah memahami pelajaran. Persis bagaimana keahlian guru membuat dongeng terkait dengan pelajaran. Guru Sekolah Kreatif Tanah Merah Bangkalan tidak hanya memantau perkembangan intelektual anakanak di sekolah tetapi perkembangan emosi, kepemimpinan, dan kepribadian. Membina model inklusif, dan komunikasi dengan orang tua juga sangat ditekankan di sekolah kreatif. Jadi, diharapkan potensi setiap anak dapat berkembang secara kreatif.

Konsep sekolah kreatif yang terinspirasi oleh konsep anak-anak harus dididik sejak 3 bulan di dalam rahim ibu. Pernyataan ini sejalan dengan teori bahwa stres emosional yang berkepanjangan selama awal kehamilan dapat menyebabkan hiperaktif kelenjar andrenalin ibu, dengan melepaskan lebih banyak hormon hidrokortison. Jika ini terjadi selama awal kehamilan, kemungkinan akan menyebabkan penyimpangan fisik dan juga keterbelakangan mental. Sebaliknya, jika terjadi pada akhir kehamilan, yaitu selama periode janin, itu tidak hanya menghasilkan hambatan mental, karena otak terus berkembang pesat saat ini, tetapi juga mengakibatkan kelahiran prematur, kesulitan kelahiran, dan kematian saat lahir. ${ }^{12}$

Ketika anak memasuki dunia sekolah, memiliki latar belakang berbeda. Karena itu, dalam proses pembelajaran sekolah kreatif menawarkan model pembelajaran dengan nama model edutainment. Dalam penerapannya, model pembelajaran edutainment di sekolah kreatif Rumah Belajar Tanah Merah Bangkalan memiliki strategi pembelajaran khusus, yaitu pembelajaran yang dikemas dalam bentuk hiburan. Akibatnya, proses pembelajaran berlangsung menyenangkan, siswa dapat lebih kreatif dalam mengekspresikan perasaan mereka dan mengeksplorasi pemahaman mereka. Selain itu, siswa diberi kebebasan penuh untuk memilih gaya belajar sesuai dengan kecenderungan belajar anak.

Hal ini sejalan dengan pendapat Mayke S. Tedjasaputra yang menekankan pentingnya bermain dalam pembelajaran karena kegiatan bermain dinikmati oleh anakanak dan dapat digunakan untuk menarik perhatian dan pengetahuan mereka. ${ }^{13}$ Bermain selain berfungsi penting untuk pengembangan pribadi, bermain sambil belajar juga memiliki fungsi sosial dan emosional. Melalui permainan juga anak-anak

\footnotetext{
${ }^{11}$ R. Rachmy Diana, setiap anak cerdas! Setiap anak kreatif! Menghidupkan Keberbakatan dan Kreativitas Anak, Jurnal Psikologi Universitas Diponegoro Vol.3 No. 2, Desember 2006.

${ }^{12}$ Elizbeth B. Hurlock. Perkembangan Anak Jilid 1. 72

${ }^{13}$ Mayke S. Tedjasaputra, Bermain, Mainan dan Permainan: Untuk Pendidikan Usia Dini, (Jakarta: Grasindo, 2001), 1-2.
} 
memahami hubungan antara mereka dan lingkungan sosial mereka, belajar untuk bergaul dan memahami aturan atau prosedur untuk berserikat. Selain itu aktivitas bermain sangat erat kaitannya dengan perkembangan kognitif anak.

Salah satu kunci dari model sekolah kreatif adalah metode pembelajaran yang disediakan oleh guru. Oleh karena itu, sekolah kreatif lebih bergantung pada bagaimana seorang guru mampu menciptakan pembelajaran yang aktif, kreatif, efektif dan menyenangkan. Untuk alasan ini, pegangan model pembelajaran adalah salah satu penawaran yang diberikan oleh sekolah kreatif. Karena itu, sebisa mungkin, dalam mengembangkan metode pembelajaran di sekolah kreatif ini dan hal-hal yang perlu diperhatikan adalah:

1. Agar siswa Aktif
a. Guru bersahabat dan bersikap terbuka
b. Guru itu mengajukan pertanyaan yang mengundang banyak jawaban siswa
c. Guru merespons dan menghargai semua jawaban siswa
d. Guru membantu siswa menyelesaikan tugas agar siswa kreatif

2. Agar Pembelajaran Efektif

a. Guru memberikan tugas yang jelas adalah salah satu faktor penting agar pembelajaran berjalan efektif.

b. Guru memperhatikan waktu

c. Guru menggunakan sumber belajar dan media pembelajaran yang sesuai

d. Guru mengakomodasi gaya belajar siswa saat presentasi

e. Guru mengelola kelas dengan baik

\section{Agar pembelajaran menyenangkan}

a. Guru itu tampak antusias, antusias dan bahagia

b. Guru menciptakan suasana belajar yang kondusif

c. Guru memanfaatkan energizer dan humor

Kreativitas adalah kunci untuk mengembangkan proses pembelajaran yang dinamis, hidup, dan menarik. Tidak selalu berarti aktivitas atau suasana yang serius. Bagi sebagian anak keseriusan lebih dirasakan sebagai ketegangan yang mudah membuat lelah. Anak-anak mungkin serius tetapi tidak sepanjang pelajaran, tidak heran awal pelajaran masih segar tetapi kemudian semakin lemah dan akhirnya anak ingin bergegas pulang. Belajar seperti ini terasa sangat membosankan. Menurut Djohar, dunia pendidikan kita telah kehilangan objektivitasnya, tidak mampu menjadi siswa yang matang, tidak bisa menumbuhkan pola pikir. Pendidikan kita hari ini adalah pendidikan yang belenggu, terlalu linier-indoktrinatif, belum mampu menghasilkan kemandirian. Pada dasarnya karena anak-anak dituntut untuk mengejar nilai tinggi, yang dalam penerapannya sistem ini hanya mengharuskan siswa untuk menghafal materi pelajaran. Pendidikan menurut David Ausubel (1963) bahwa materi pembelajaran harus "bermakna". Pembelajaran yang bermakna adalah proses menghubungkan informasi baru dengan konsep-konsep relevan yang 
terkandung dalam struktur kognitif anak, sementara pendidikan hafalan dan pergeseran adalah bentuk pendidikan yang tidak berarti. ${ }^{14}$

Selain itu, guru memiliki peran besar di sekolah kreatif. Guru sebagai pendidik amerupakan salah satu faktor penentu keberhasilan setiap upaya pendidikan di sekolah kreatif. Tugas dan peran guru tidak terbatas pada masyarakat. Dalam proses mengajar guru memiliki banyak peran sehingga dapat menciptakan kondisi belajar yang efektif. Untuk dapat mengajar secara efektif, guru harus meningkatkan kesempatan belajar bagi siswa dan meningkatkan kualitas pengajaran. Dengan memberikan kesempatan belajar bagi siswa untuk terlibat aktif dalam pembelajaran. Semakin banyak siswa terlibat aktif dalam pembelajaran, semakin tinggi pula prestasi belajar yang mereka raih. Sedangkan dalam meningkatkan kualitas pembelajaran guru harus dapat merencanakan program pengajaran dan juga dapat menerapkan dalam bentuk interaksi belajar mengajar.

Paolo Freire berpendapat yang dijelaskan dalam model pendidikannya sebagai "Pendidikan Hadap Masalah" (Problem Posing Education), yaitu anak didik menjadi subyek yang belajar, subyek yang bertindak dan berpikir, dan pada saat bersamaan berbicara menyatakan hasil tindakan dan buah pikirannya, dan begitu juga guru. ${ }^{15} \mathrm{Jadi}$, keduanya (murid dan guru) saling belajar satu sama lain, saling memanusiakan.

Sesuai dengan tujuan sekolah kreatif, yaitu meningkatkan kualitas pendidikan dasar sesuai dengan perkembangannya, meningkatkan prestasi di bidang minat bakat sesuai dengan potensi anak, memiliki keunggulan, imajinatif, kreatif, dan inovatif dalam karakter, agama, demokrasi. Sekolah kreatif dalam upaya mewujudkan fungsi pendidikan sebagai wahana sumber daya manusia, perlu mengembangkan iklim belajar mengajar yang konstruktif untuk pengembangan potensi kreatif anak bersama dengan pengembangan atmosfer, kebiasaan dan strategi belajar mengajar. Berdasarkan pada pemahaman sains, kreativitas, kurikulum yang berbeda dan implikasinya. Mungkin, salah satu kendala dalam pembelajaran kreatif adalah garis batas antara disiplin ilmu, terutama antara seni dan ilmu pengetahuan dalam kurikulum pendidikan formal saat ini. Jadi untuk menciptakan suasana pembelajaran kreatif, perlu menerapkan perspektif lintas disiplin dan menumbuhkan sinergi kreatif melalui berbagai pendekatan. ${ }^{16}$

\section{Sekolah Kreatif dengan Pengembangan Metode Kreatif}

Sekolah kreatif adalah salah satu bentuk organisasi dan struktur sederhana dalam organisasi sekolah. Interaksi terjadi di antara para anggotanya termasuk guru,

\footnotetext{
${ }^{14}$ David Ausubel, The Psycholoy of meaningful verbal Learning, (New York : Grune \& Stratton Publishers, 1999), 30.

15 Paulo Freire. Politik Pendidikan: Kebudayaan, Kekuasaan Dan Pembebasan. (Yogyakarta: Pustaka Pelajar, 2002), xv

${ }^{16}$ Eng Hock Chia. Anda Juga Bisa Menjadi Kreatif: Menerapkan Pemikiran Kreatif dalam Kehidupan Sehari-Hari (Jakarta: Prestasi Pustakarya, 2000), 12
} 
siswa, kepala sekolah, orang tua siswa, yang didukung oleh infrastruktur. Sebagai sebuah organisasi, sekolah memiliki visi, misi dan strategi untuk mencapai tujuan. Dalam mewujudkan visi, misi, dan strategi sekolah, diperlukan hubungan antara iklim sekolah dan kecerdasan emosional siswa dengan prestasi belajar siswa manajemen di bawah kepemimpinan kepala sekolah. ${ }^{17}$

Sekolah juga merupakan sistem yang kompleks karena selain terdiri dari input-proses-output, mereka juga memiliki akuntabilitas dalam konteks pendidikan dan hasil. Konteks pendidikan berbeda dari organisasi lain karena pendidikan mengharapkan output atau produk tidak hanya secara kuantitatif, tetapi hasil lulusan yang berguna di lingkungan mereka sesuai dengan proses yang dilakukan. Output pendidikan adalah fokus dari upaya pendidikan, dan input adalah input penting untuk output, tetapi jauh lebih penting adalah bagaimana memanfaatkan input ini dalam kaitannya dengan individu dan sumber daya lain yang tersedia di sekolah. Ini menjelaskan posisi komponen sistem yang outputnya memiliki tingkat kepentingan tertinggi. Proses memiliki tingkat kepentingan satu tingkat lebih rendah dari output, dan input memiliki tingkat kepentingan dua tingkat lebih rendah dari output. ${ }^{18}$

Secara substansial, sekolah kreatif sebenarnya identik dengan sekolah yang efektif. Karena alasan ini, sejumlah hal yang akan mencakup sekolah yang efektif meliputi:

\section{Input}

Selain sebagai wahana belajar, lingkungan juga merupakan tempat berasalnya masukan (input) sekolah. Input sekolah adalah semua input yang dibutuhkan oleh sekolah untuk pemrosesan untuk mendapatkan output yang diharapkan. Input adalah bahan yang dibutuhkan untuk membuat generasi yang disebut manusia penuh. Mengenai input sekolah dapat diidentifikasi, antara lain:19

a. Manusia (man)

Manusia yang dibutuhkan sebagai masukan bagi proses pendidikan adalah siswa sebagai bahan utama atau bahan mentah. Untuk menghasilkan manusia seutuhnya diperlukan manusia yang memiliki potensi untuk dididik, dilatih, dibimbing, dan dikembangkan menjadi manusia seutuhnya. Untuk itu, diperlukan manusia lain yang bertugas sebagai tim sukses untuk membentuk manusia seutuhnya.

Kepemimpinan seorang kepala sekolah diharapkan mampu memberdayakan guruguru untuk melaksanakan proses pembelajaran dengan baik, lancar, dan produktif serta menyelesaikan tugas dan pekerjaan sesuai dengan waktu yang ditetapkan. Kepala sekolah sebagai manajer sekolah tentu saja harus bekerja dengan sebuah tim yang solid dengan "para pemain" dari kalangan guru dan karyawan.

b. Uang (money)

\footnotetext{
${ }^{17}$ Mudjijana, R. Hubungan Antara Iklim Sekolah dan Kecerdasan EmosionalSiswa dengan Prestasi Belajar Siswa. Jurnal Pendidikan Penabur- No.02/Th.III/ Maret 2004.

${ }^{18}$ Aan Komariah dan Cepi Triatna, Visionary Leadership "Menuju Sekolah Efektif” .,1-2

${ }^{19}$ Ibid., 2
} 
Uang merupakan masukan yang melancarkan sebuah proses raw input. Walaupun bukan yang paling esensial, tetapi jika tidak ada uang upaya perwujudan manusia seutuhnya diragukan karena terkait dengan proses pembelajaran. Kedudukan uang dalam input pendidikan sangat penting karena untuk membiayai segala program yang telah ditetapkan. Keuangan sekolah berasal dari pemerintah, masyarakat, dan orang tua.

c. Material (Materials)

Bahan fisik yang diperlukan untuk menunjang terjadinya proses pembelajaran di sekolah membentuk siswa seutuhnya. Adapun material tersebut berupa sarana prasarana, alat-alat pendidikan atau media dan sumber pendidikan.

d. Metode (Methods)

Dalam pendidikan lebih dikhususkan pada metode pembelajaran, yaitu cara-cara, teknik, strategi yang dikembangkan sekolah dalam melaksanakan proses pendidikan. Salah satu dari metode dalam pembelajaran adalah metode edutainment. Penggunaan metode edutainment mengajak siswa belajar melalui bermain untuk mengekspresikan emosi siswa melalui kegiatan tersebut yang kemudian diajak mengerjakan materi pelajaran pada saat itu. Mengenal benda dan obyek secara kongkret dengan pembelajaran di luar kelas, memberikan ruang gerak yang cukup dan mendorong berkembangnya daya nalar dan kreativitas anak.

Menurut Bobbi Deporter perintis supercamp yaitu program pembelajaran dan pelatihan bagi siswa agar kecerdasannya bertambah dua kali lipat dari sebelumnya dengan menggabungkan Neuro Linguistik Programming (NLP), sugestologi, accelerated learning (teori pemercepatan belajar). Maksud dari Neuro Linguistik Programming adalah pemrograman bahasa syaraf yang mencoba menggabungkan kekuatan otak kiri dan kanan serta pikiran bawah sadar agar seseorang dapat menyerap segala informasi dan belajar hal-hal baru dengan cepat. Gelombang otak dibagi menjadi empat yaitu alpha, tetha, beta, dan delta.

Alpha adalah kondisi saat otak kita benar-benar jernih dan berada pada satu titik sempurna untuk mengingat dan memahami segala sesuatu. Tetha adalah keadaan saat kita tidur tetapi bermimpi sehingga mata kita bergetar lebih cepat dari biasanya. Dalam istilah psikologi dan kedokteran biasa disebut dengan REM (Rapid Eye Movement) dan di sinilah tubuh melakukan penyembuhan fisik dan mental secara alami. Beta terjadi saat kita sedang melakukan aktivitas yang menuntut konsentrasi terpecah seperti saat mengendarai mobil. Sedangkan yang terakhir adalah delta yang berlangsung saat otak istirahat penuh yaitu waktu kita tidur dan tidak bermimpi sama sekali.

e. Mesin-Mesin (Machines)

Mesin merupakan perangkat pendukung terjadinya proses pembelajaran, yaitu dapat berupa teknologi komputer, radio, televisi, mobil atau media-media yang menggunakan teknologi. Alat-alat tersebut dipergunakan sekolah, baik sebagai daya dukung maupun sebagai obyek untuk dipelajari. 
Pendidikan di Indonesia, menurut Djohar, telah kehilangan objektivitasnya, tidak mampu menjadi siswa yang matang, tidak dapat mengembangkan pola pikir. Pendidikan kita hari ini adalah pendidikan yang belenggu, terlalu linier-indoktrinatif, belum mampu menghasilkan kemandirian. Pada dasarnya, beberapa hasil di atas dari tuntutan siswa untuk mengejar NEM tinggi, yang dalam praktiknya sistem ini hanya mengharuskan siswa untuk selalu menghafal materi pelajaran. David Ausuble mengatakan bahwa menghafal merupakan bentuk pendidikan yang tidak berarti. Pendidikan seperti ini adalah pendidikan yang terbelenggu dan tidak manusiawi. ${ }^{20}$

Kreativitas sebagai kunci untuk mengembangkan kegiatan pembelajaran yang dinamis, hidup, dan menarik. Tidak selalu berarti aktivitas atau suasana yang serius. Bagi sebagian anak keseriusan lebih dirasakan sebagai ketegangan yang mudah membuat lelah. Anak-anak mungkin serius tetapi tidak sepanjang pelajaran, tidak heran awal pelajaran masih segar tetapi kemudian menjadi lamban dan malas untuk cepat pulang kerumah karena belajar terasa sangat membosankan.

Setiap anak memiliki sifat dan latar belakang yang berbeda dari masing-masing individu. Akan tetapi kegiatan belajar adalah sebuah proses belajar yang direncanakan. Setiap guru mampu menciptakan suasana belajar yang gembira dan penuh semangat. Inilah pembelajaran yang kreatif dan sangat efektif dalam pencapaian tujuan. Dalam buku Quantum Teaching, Menciptakan suasana kelas digambarkan bagaikan sebuah grup orkestra. Setiap siswa memiliki berbagai kekhasannya masing-masing dan guru adalah dirigen yang menjadikannya menghasilkan suara/musik yang harmonis. Bagaimana menciptakan suasana belajar yang hidup dan menyenangkan anak? Ubahlah paradigma bahwa kelas adalah beban berat, malas atau menakutkan menjadi sebuah suasana yang kita tunggu serta menyenangkan. Bayangkan betapa kita dibutuhkan oleh anak-anak. Singkirkan berbagai "masalah" kita, apalagi menjadikan kelas sebagai pelampiasan atau sasaran kekesalan. Awali masuk kelas dengan senyum ramah, pancaran kegembiraan kita akan menular ke seisi kelas.

Manfaatkan potensi anak, jika di kelas ada anak yang jago bercanda atau pandai bicara kita harus memamfaatkannya. Nikmati kebersamaan dengan mereka, jangan takut kita akan menjadi "kekanak-kanakan" atau takut kehilangan otoritas. Selalu memulai dan akhiri proses belajar yang menyenangkan yang melibatkan anak-anak. Hilangkan kebiasaan mengakhiri pelajaran dengan memberikan tugas disertai ancaman / sanksi yang membuat anak takut atau malas dengan pelajaran kita. Ini berarti bahwa guru adalah pemimpin di kelas yang menentukan arah dan pencapaian tujuan pembelajaran, oleh karena itu kegiatan pembelajaran yang dikembangkan harus berorientasi pada siswa, karena siswa memiliki kebebasan untuk mengembangkan kompetensi mereka.

Kegiatan belajar penuh dengan aktivitas anak, penuh tawa, bahkan sedikit riuh bukanlah kegiatan yang tidak berarti, tetapi harus diarahkan untuk mencapai tujuan pembelajaran. Suasana bahagia membuat anak-anak tampak memiliki energi ganda

${ }^{20}$ David Ausubel, The Psycholoy of meaningful verbal Learning, 30. 
sehingga mereka tidak lelah atau mengantuk. Proses pembelajaran semacam itu adalah teknik yang efektif untuk merangsang kreativitas belajar dan siswa tidak mudah lelah, suasana seperti ini akan membuat kelas menjadi menyenangkan dan siswa menjadi dekat satu sama lain. Dari penjelasan di atas peneliti dapat menarik benang merah bahwa sekolah kreatif adalah sekolah dengan pembelajaran yang penuh kreativitas, dengan desain pembelajaran yang sedemikian rupa serta memberikan bentuk kebebasan terhadap anak didik ketika proses belajar mengajar.

Konsep sekolah kreatif juga membutuhkan peran besar seorang guru yang benarbenar memahami konsep tersebut. Sebagai guru atau pendidik merupakan salah satu faktor penentu bagi keberhasilan setiap upaya pendidikan di sekolah kreatif. Tugas dan peran guru tidak terbatas pada masyarakat, bahkan guru pada dasarnya adalah komponen strategis yang memiliki peran penting dalam menentukan kemajuan kehidupan bangsa. Dalam mengajar anak-anak, para guru dituntut untuk memiliki peran ganda sehingga dapat menciptakan kondisi belajar yang efektif. Untuk dapat mengajar secara efektif, guru harus meningkatkan kesempatan belajar bagi siswa dan meningkatkan kualitas pengajaran. Dengan memberikan kesempatan belajar bagi siswa untuk melibatkan diri secara aktif dalam pembelajaran. Semakin banyak siswa terlibat aktif dalam pembelajaran, semakin tinggi kemungkinan prestasi belajar tercapai. Sedangkan dalam meningkatkan kualitas pembelajaran guru harus dapat merencanakan program pengajaran dan pada saat yang sama dapat melakukannya bentuk interaksi dalam proses belajar mengajar.

\section{Peran Sekolah Kreatif dalam Mengembangkan Aspek Psikomotorik Anak}

Sekolah adalah organisasi sosial yang menyediakan layanan pembelajaran bagi masyarakat. ${ }^{21}$ Sekolah juga memainkan peran penting dalam pendidikan karena pengaruhnya sangat besar pada jiwa anak-anak. Jadi selain keluarga sebagai pusat pendidikan, sekolah juga memiliki fungsi sebagai pusat pendidikan untuk pembentukan pribadi anak. Sekolah merupakan tempat atau lembaga pendidikan kedua setelah keluarga, terutama yang memiliki fungsi melanjutkan pendidikan keluarga. ${ }^{22}$

Mengingat pentingnya fungsi sekolah dalam pembentukan pribadi anak, pendidikan sekolah kreatif Rumah Belajar Tanah Merah Bangkalan menyediakan modelnya sendiri dalam proses pembelajaran yang dikenal sebagai model pembelajaran Edutainment. Dalam konsep pembelajaran edutainment, semangat belajar yang menyenangkan, nyaman dan menakjubkan dan juga bagaimana hubungan antara guru dan siswa dapat terjalin dengan pendekatan didaktik metodis bernuansa "Redagogical". Dalam arti bahwa "interaksi antara guru dan siswa dibangun oleh komunikasi yang menyenangkan dan harmonis" sebagai guru harus fleksibel, intim dan ramah seperti

${ }^{21}$ Aan Komariah, dan Cepi Triatna, Visionary Leadership “Menuju Sekolah Efektif”,., 2

${ }^{22}$ Abu Ahmadi, Ilmu Pendidikan (Jakarta: Rineka Cipta, 1991), 180 
temannya sendiri. Dengan begitu siswa tidak merasa dibatasi, takut dan dapat berinteraksi secara bebas dan menyenangkan. ${ }^{23}$

Pilihan model pembelajaran edutainment ini juga didasarkan pada hasil penelitian tentang bagaimana otak bekerja. Penemuan terbaru ini bahwa anak-anak akan belajar secara efektif ketika dalam keadaan senang dan bebas dari tekanan (revolutional learning). ${ }^{24}$ Pelajaran yang dipraktekkan dikemas dalam suasana bermain dan bereksperimen, sehingga belajar tidak lagi membosankan, melainkan pembelajaran dan arena yang menyenangkan bagi siswa. Mengenai bentuk-bentuk aplikasi pembelajaran edutainment di sekolah kreatif adalah:

1.Belajar melalui permainan seperti mengajak siswa untuk memotong atau melipat, membentuk dan mewarnai selembar kertas kerja sehingga gambar atau model favorit mereka dibentuk sesuai dengan topik atau tema yang sedang dibahas pada waktu itu.

2. Mengetahui benda dan benda secara konkret, sehingga belajar di luar kelas menjadi bagian yang sangat penting. Seperti, beajar tentang bercocok tanam, maka siswa akan diajak langsung mengunjungi sawah dan sekaligus mengenalkan musim hujan/cuaca. Contoh lain yaitu siswa juga diajarkan menanam pohon hias untuk menjaga lingkungan yang bersih dan sehat.

3. Tidak bergantung pada sebuah ruangan dalam proses belajar-mengajar, melainkan siswa dapat memilih lokasi belajar yang diinginkan, para guru juga memanfaatkan lingkungan sekitar desa sebagai tempat belajar.

4. Belajar diatur secara terpadu yang "terikat" melalui tema-tema tertentu. Tema ini dipecah menjadi beberapa sub tema.

5. Lembar kerja kreatif (LKK) dibuat bervariasi dan kreatif menggunakan banyak kertas. Setelah diperiksa dan dikomentari oleh guru, koleksi pekerjaan siswa ditunjukkan kepada wali siswa melalui siswa atau pertemuan dengan wali siswa setidaknya setiap bulan.

6. Sekolah kreatif tidak menggunakan buku pelajaran tertentu, keseragaman dan keterbatasan literatur dihindari sehingga siswa dapat memperoleh materi pembelajaran dari sumber apa pun asalkan relevan seperti dari berhitung dengan memanfaatkan dedaunan, tumbuh-tumbuhan,bambu,dll.

Strategi pembelajaran edutainment, guru harus kreatif tidak diperbolehkan memberi label negatif, seperti: dilarang marah, berkata kasar atau sesuatu yang bisa mengurangi energi positif, antusiasme dan rasa percaya diri siswa. Meskipun siswa membuat kesalahan, guru diperbolehkan untuk mengingatkan mereka dalam bahasa mereka dan sesuai dengan psikologi anak dengan arahan atau kata-kata sopan, baik dan mendidik. Dalam proses pembelajaran, siswa diberikan kebebasan untuk bergerak baik dalam mengekspresikan ide, pikiran dan kebebasan berekspresi dan berkreasi dan tidak ada tekanan yang membuat siswa takut, inferior atau hal-hal lain yang dapat

\footnotetext{
${ }^{23}$ Moh Sholeh Hamid, Metode Edutainment, (Yogyakarta: Diva press, 2014), 17

${ }^{24}$ Ibid., 19
} 
menghambat kreativitas siswa. Sekolah kreatif memberikan kebebasan kepada anak untuk belajar menjadi anak yang berani, percaya diri, kreatif dan inovatif. Kondisi lingkungan kelas dimodelkan dengan menyenangkan, untuk memancing imajinasi, kreativitas dan mendukung antusiasme siswa untuk berekspresi. Ini terbukti dalam desain kelas di alam terbuka yang tentunya berbeda dari sekolah-sekolah pada umumnya. Di alam terbuka dapat merangsang pemikiran dan kreativitas siswa, sehingga proses pembelajaran berlangsung menikmati, menyenangkan dan penuh keceriaan.

Hubungan antara guru dan siswa di sekolah kreatif harmonis dan penuh keintiman dengan hampir tanpa isolasi, meskipun terus terjadi dalam batas-batas saling menghormati. Guru seperti teman bagi siswa. Di sinilah siswa belajar tentang kreativitas, tidak ada rasa takut akan apa pun yang menghalangi hati siswa. Siswa bebas mengekspresikan ide, pendapat dan ekspresi, sehingga siswa dapat belajar lebih menikmati, penuh antusiasme dan lebih bermakna. Dan sekolah kreatif ini juga memberikan kebebasan baik dalam mengenakan pakaian maupun dalam memilih buku pelajaran (sumber belajar) karena sekolah memberikan kebebasan berpakaian.

Dalam proses pembelajaran edutainment, suasana kelas selalu diciptakan dengan kondisi yang ceria, menyenangkan dan penuh antusiasme, sehingga pembelajaran berlangsung sangat menyenangkan. Agar kelas tetap ceria dan penuh kreativitas, kelas selalu dirancang seaktif mungkin, dengan tujuan mengembangkan kreativitas siswa. Untuk menciptakan suasana yang menyenangkan, guru harus selalu dapat berkoordinasi, mengkondisikan siswa, membangkitkan motivasi siswa dan dapat merancang kelas dan memilih metode yang sesuai dengan psikologi dan gaya belajar siswa. Dengan pembelajaran edutainment seperti dijelaskan di atas, evaluasi model konvensional tidak lagi memadai. Oleh karena itu, modifikasi dan peningkatan dilakukan dalam cara mengevaluasi. Penilaian tidak hanya kuantitatif (angka pada kartu laporan) tetapi juga secara kualitatif dalam bentuk narasi. Proses evaluasi tidak hanya kompetensi akademik dan keterampilan psikomotorik, tetapi juga keterampilan sosial, kepribadian dan kepemimpinan.

Dalam mengembangkan aspek psikomotor anak-anak di sekolah kreatif memberlakukan aturan, dari anak usia 3 tahun hingga 9 tahun, anak dibiarkan sebebas mungkin untuk memilih keinginannya. Ruang kelas di alam terbuka, yang memungkinkan anak-anak meninggalkan kelas seperti yang mereka inginkan jika mereka tidak ingin mengambil pelajaran. Tentu saja, ketika anak-anak meninggalkan kelas, tidak dibiarkan begitu saja. Guru bisa mengikuti kemana dia pergi. Misalnya, jika ia tiba-tiba bermain tanah liat, guru di sekolah kreatif akan menemaninya bermain. Di situlah pelajaran dimasukkan.

Perkembangan anak-anak hingga usia 9 tahun berjalan seiring dengan kelincahan gerakan mereka. Sehingga semakin banyak mereka bermain dan bergerak, memberi potensi pengembangan yang lebih baik. Hampir semua sekolah di Indonesia mendisiplinkan anak-anak sedemikian rupa sehingga anak-anak tidak dapat melakukan 
apa pun. Jika ada anak yang terlihat usil dan agak nakal, mereka akan dimarahi dan diberi hukuman. Ini menurut saya, adalah pola pendidikan yang salah. ${ }^{25}$

Dunia anak-anak adalah dunia bermain. Tentu dengan bermain, anak belajar berbagai hal. Dengan bermain, berbagai kemampuan dasar anak-anak bias berkembang, seperti keterampilan psikomotorik yang dikembangkan melalui permainan: berjalan, berlari, melompat, memanjat, melempar, menangkap, berdiri dengan satu kaki, berjinjit, berguling dan sebagainya. Untuk mendukung perkembangan psikomotor anak-anak sekolah kreatif menyediakan tepat bermain seperti lompat tinggi dan permainan tradisonal lainnya. Hal itu bertujuan untuk mengasah kemampuan psikomotor siswa yang takut ketinggian. Dan juga belajar berhitung melalui permainan engkle', yang bertujuan untuk melatih siswa untuk banyak bergerak dalam proses belajar, sehingga diharapkan dengan proses perpindahan yang telah dikeluarkan semua ini meningkatkan kreativitas siswa dan menghilangkan rasa takut pada siswa sehingga siswa menjadi percaya diri dalam menjelajahi semua dalam dirinya.

Ketika proses aktualisasi gerakan siswa, dengan penyediaan taman bermain ini, tentu saja, tidak hanya dirilis oleh seorang guru, tetapi guru juga bermain dengan siswa, dari mana kemudian sedikit demi sedikit materi pembelajaran dimasukkan untuk siswa. Karena belajar sambil bermain akan membuat anak lebih bersemangat, nyaman dan menyenangkan. Selain itu, sekolah kreatif selalu menumbuhkan kepercayaan diri siswa dengan menampilkan siswa di depan rekan-rekan mereka dalam bentuk pertunjukan dan seni, assembly, atau out bound yang sesuai dengan kemampuan anak. Selain itu siswa juga dibiasakan untuk tampil didepan publik, baik melalui acara lomba intern untuk mewadahi potensi siswa, sekolah kreatif banyak mengadakan lomba-lomba seperti lomba-lomba pada 17 Agustus (lomba keterampilan, lomba menari, adzan dan tilawah) yang diikuti anak dari usia 3 tahun sampai 9 tahun. ${ }^{26}$

Sekolah kreatif berpartisipasi dalam lomba, adalah salah satu acara internal sekolah untuk membuat siswa terbiasa tampil di depan umum. Dengan acara ini diharapkan dapat meningkatkan potensi anak dan mengembangkan kreativitas psikomotorik anak-anak baik dalam belajar maupun bekerja. Sekolah memiliki peran yang sangat penting dalam perkembangan mental anak-anak. Setelah anak mencapai usia tiga tahun, anak keluar dari lingkungan keluarga dan memasuki lingkungan sekolah, yang merupakan pengaruh besar pada perkembangan fisik dan spiritual. Mereka mengenal lebih banyak teman di lingkungan sosial yang lebih luas, sehingga peran sosial mereka meningkat. Dia ingin tahu banyak hal di sekitarnya sehingga pengalamannya meningkat.

Dalam mengembangkan aspek psikomotor anak-anak sekolah kreatif Rumah Belajar Tanah Merah Bangkalan menawarkan warna yang berbeda dalam memunculkan kreativitas siswa, di antaranya selalu menumbuhkan kepercayaan diri anak dengan menampilkan anak di depan rekan-rekan mereka dalam bentuk pementasan dan seni,

${ }^{25}$ Imrotin Hasanah, Wawancara 9 Maret 2020

${ }^{26}$ Dokumentasi Sekolah Kreatif Rumah Belajar Tanah Merah Bangkalan 
assembly atau out bound terikat sesuai dengan kemampuan anak. Dengan menggunakan model pembelajaran edutainment di sekolah kreatif, kemampuan psikomotor anak dapat dikembangakn melaui model pembelajaran permainan seperti mengundang siswa untuk memotong atau melipat, membentuk dan mewarnai selembar kertas kerja sehingga gambar atau model favorit mereka dibentuk sesuai dengan topik atau tema yang sedang dibahas saat itu. Setelah emosi siswa terinspirasi melalui kegiatan tersebut, maka mereka diundang untuk mengerjakan materi pelajaran sesuai dengan tema atau materi pelajaran yang sedang dibahas.

Selain itu, dalam mengembangkan aspek psikomotor anak-anak di sekolah kreatif yang diikuti anak mulai usia 3 tahun sampai 9 tahun, anak dibiarkan sebebas mungkin untuk memilih keinginannya. Perkembangan anak-anak hingga usia 9 tahun berjalan seiring dengan kelincahan mereka. Sehingga semakin banyak mereka bermain dan bergerak, maka semakin mengembangkan potensi anak yang lebih baik. Hampir semua sekolah di Indonesia mendisiplinkan anak-anak sedemikian rupa sehingga anak-anak tidak dapat melakukan apa pun. Jika ada anak yang terlihat usil dan agak nakal, mereka akan dimarahi dan diberi hukuman. Ini menurut saya, adalah pola pendidikan yang salah. ${ }^{27}$

Hal Ini sejalan dengan alasan untuk mempelajari perkembangan psikomotorik yang ideal yaitu selama masa kanak-kanak. Pertama, karena tubuh anak lebih fleksibel daripada tubuh remaja atau dewasa, sehingga anak-anak lebih mudah menerima semua pelajaran. Kedua, anak-anak belum memiliki banyak keterampilan yang akan berbenturan dengan keterampilan yang baru saja mereka pelajari, sehingga lebih mudah bagi anak-anak untuk mempelajari keterampilan baru. Ketiga, anak-anak secara keseluruhan lebih berani ketika mereka kecil dari pada ketika mereka dewasa. Karena itu, mereka lebih mau mencoba sesuatu yang baru. Hal semacam ini memunculkan motivasi yang dibutuhkan dalam belajar. Keempat, ketika sudah usia remaja dan dewasa sudah merasa bosan melakukan pengulangan seperti waktu usia anak-anak. Karena itu, anak rela mengulangi suatu tindakan hingga pola otot dilatih untuk melakukannya secara efektif. Kelima, karena anak-anak memiliki tanggung jawab dan kewajiban yang lebih kecil dari pada ketika mereka semakin besar, mereka memiliki lebih banyak waktu untuk belajar menguasai keterampilan daripada remaja atau orang dewasa. ${ }^{28}$ Selain itu, kreativitas ini juga lahir dari proses aktualisasi diri yang berkesinambungan. Seperti yang disinggung Rogers, sumber kreativitas adalah kecenderungan untuk mengaktualisasikan diri, menyadari potensi, dorongan untuk berkembang dan menjadi dewasa, kecenderungan untuk mengekspresikan dan mengaktifkan semua kemampuan organisme.. ${ }^{29}$

Inti dari semua konsep kreativitas adalah unsur pembaruan. Hasil kreativitas adalah cara berpikir atau melakukan sesuatu yang baru, asli, bebas dan imajinatif.

\footnotetext{
${ }^{27}$ Fatwatun Nafila, Wawancara 10 Maret 2020

${ }^{28}$ Elizbeth B. Hurlock. Perkembangan Anak Jilid 1, 156

${ }^{29}$ Utami Munandar, Kreativitas dan Keberbakatan: Strategi Mewujudkan Potensi Kreatif dan Bakar, (Jakarta: Grafindo Pustaka Utama, 2002), 24.
} 
Dengan kata lain, kreativitas adalah pemikiran atau pemecahan masalah yang original dan imajinatif. Untuk dapat melahirkan kreativitas, seseorang harus dapat memanfaatkan kedua otak kiri dan kanan. Otak kiri yang logis, berurutan, verbal, akresi dan dominan. Sedangkan otak kanan bersifat emosional, melompat, visual, holistik dan tersembunyi. Akhir-akhir ini, istilah otak kanan telah digunakan sebagai cara populer untuk mengekspresikan kreatif, artistik, dan rapi. Kreativitas muncul dari interaksi luar biasa antara kedua otak. Jadi standar kreativitas dapat ditarik adalah unik, berbeda, baru dan lebih baik dan berguna. Orang-orang kreatif membawa makna dan tujuan baru, memecahkan masalah dan memberikan nilai tambah atau keindahan.

\section{Kesimpulan}

Konsep sekolah kreatif yang dikembangkan oleh rumah belajar Tanah Merah Bangkalan berfokus pada konsep inovatif yang diterapkan oleh rumah belajar Tanah Merah Bangkalan. Sekolah kreatif memberikan kebebasan kepada anak-anak untuk membuat dan berinovasi tanpa harus terlalu ketat diatur oleh peraturan sekolah. Intinya, mereka bisa belajar sambil bermain. Karena pada usia muda, mulai usia 3 hingga 9 tahun hingga anak-anak sekolah dasar kelas 5 kreasi kognitif dan psikomotorik berkembang bersama dengan gerakan tubuh mereka. Peran sekolah kreatif dalam mengembangkan aspek psikomotor anak dapat dilihat dengan model pembelajaran yaitu model pembelajaran edutainment yang kreatif, inovatif dan memahami aspek psikologis anak, dengan penerapan regulasi, mulai dari anak usia 3 hingga 9 tahun yang dibiarkan bebas untuk memilih keinginannya. Ruang kelas dibiarkan terbuka, yang memungkinkan anak-anak meninggalkan ruang kelas seperti yang mereka inginkan jika mereka tidak ingin mengambil pelajaran, tentu saja guru mengikuti mereka. Selain itu, karya siswa ditampilkan di kelas untuk mengeksplorasi keterampilan psikomotor siswa. Layanan fasilitas bermain seperti lompat tinggi dan berhitung melalui permainan engkle' pada halaman sekolah serta penyediaan tali seperti jaring laba-laba yang bertujuan untuk taman bermain siswa, yang baik untuk melepaskan kekuatan siswa dalam mengaktualisasikan diri mereka.

\section{Daftar Rujukan}

Ahmadi, Abu. Ilmu Pendidikan, Jakarta: Rineka Cipta, 1991.

Ausubel, David. The Psycholoy of meaningful verbal Learning,New York : Grune \& Stratton Publishers, 1999.

Denim, Sudarwan. Visi Baru Manajemen Sekolah, Jakarta: Bumi Aksara, 2006.

Diana, R. Rachmy setiap anak cerdas! Setiap anak kreatif! Menghidupkan Keberbakatan dan Kreativitas Anak, Jurnal Psikologi Universitas Diponegoro Vol.3 No. 2, Desember 2006.

Elizbeth B. Hurlock. Perkembangan Anak Jilid 1. Jakarta: Erlangga, 1997. 
Eng Hock Chia. Anda Juga Bisa Menjadi Kreatif: Menerapkan Pemikiran Kreatif dalam Kehidupan Sehari-Hari, Jakarta: Prestasi Pustakarya, 2000.

Hamid, Moh Sholeh. Metode Edutainment,Yogyakarta: Diva press, 2014.

Komariah, Aan dan Cepi Triatna, Visionary Leadership "Menuju Sekolah Efektif” Jakarta: Bumi Aksara, 2006.

Mudjijana, R. Hubungan Antara Iklim Sekolah dan Kecerdasan EmosionalSiswa dengan Prestasi Belajar Siswa. Jurnal Pendidikan Penabur- No.02/Th.III/ Maret 2004.

M. Dahlan Y. Al-Barry. Kamus Induk Ilmiah Seri Intelektual, Surabaya: Target Press 2003.

Mayke S. Tedjasaputra, Bermain, Mainan dan Permainan: Untuk Pendidikan Usia Dini, Jakarta: Grasindo, 2001.

Paulo Freire. Politik Pendidikan: Kebudayaan, Kekuasaan Dan Pembebasan. Yogyakarta: Pustaka Pelajar, 2002.

Pusat Bahasa Departemen Pendidikan Nasional. Kamus Besar Bahasa Indonesia Edisi Kedua. Jakarta: Balai Pustaka, 2002.

Sutrisno, Revolusi Pendidikan di Indonesia: Membedah Metode dan Teknik Pendidikan Berbasis Kompetensi, Yogyakarta: Ar-Ruzz, 2005.

Utami Munandar, Kreativitas dan Keberbakatan: Strategi Mewujudkan Potensi Kreatif dan Bakar, Jakarta: Grafindo Pustaka Utama, 2002.

Wijayanti, Ari. Pengajaran Bahasa yang Kreatif. http:// blogroll. Maret 3, 2020.

https://www.kompas.com/kompas-cetak/0312/08/Didaktika/722842.htm.

Pendidikan dan Sensitivitas Guru yang Kreatif. Senin,08 Maret 2020.

Dokumentasi Sekolah Kreatif Rumah Belajar Tanah Merah Bangkalan

Fatwatun Nafila, Wawancara 10 Maret 2020

Imrotin Hasanah, Wawancara 9 Maret 2020

Laila Munawarah, Wawancara, Wakil Direktur Rumah Belajar , 8 Maret 2020. 